\title{
SIMULATION MODEL OF ENERGY BALANCE FOR POULTRY HOUSES
}

\author{
Manar A. Saad*, El-Sayed G. Khater**, \\ Samir A. Ali** and Taha H. Ashour**
}

ABSTRACT

The main aim of this research was to develop a simulation model of energy balance of the poultry house to predict the energy gain or loss of poultry houses that made of different materials in order to save energy and reduce costs. This could be achieved through studying the external loads are transmission, fenestration, perimeter, ventilation and infiltration at different poultry houses. The results showed that the energy requirement for heating poultry house decreases with increasing chicken age (40 days). The energy requirement for heating was decreased from 3716.75 to $247.65,2731.31$ to $10.79,2417.98$ to 66.14 and 2418.06 to $66.18 \mathrm{Kwh}$ for first, second, third and fourth houses, respectively, when the chicken age increased from 1 to 40 days in Faiyum city. The energy requirement for heating was decreased from 6602.23 to 701.29, 5030.31 to 364.65, 4534.72 to 255.98 and 4534.86 to $255.99 \mathrm{Kwh}$ for first, second, third and fourth houses, respectively, when the chicken age increased from 1 to 40 days in Benha city. The energy requirement for ventilation was increased from 1517.24 to $4083.08,1325.53$ to 3326.87, 1262.20 to 3084.95 and 1262.21 to $3085.00 \mathrm{Kwh}$ for first, second, third and fourth houses, respectively, when the chicken age increased from 1 to 40 days in Faiyum city. The energy requirement for ventilation was increased from 2373.09 to $6793.56,1991.44$ to $5477.08,1867.80$ to 5060.30 and 1867.81 to $5060.41 \mathrm{Kwh}$ in Benha city, when the chicken age increased from 1 to 40 days. The model results were in a reasonable agreement with the experimental ones.

Keywords: Simulation Model - Energy - Chicken House - Heating Ventilation

\footnotetext{
* Graduate Student of Agric. Eng. Dep., Fac. of Agric., Benha Univ., Egypt. ** Fac. of Agric., Benha Univ., Egypt.
} 


\section{INTRODUCTION}

The environmental conditions inside livestock houses play an important role for improving the performance and welfare of the

1 animals in the farms. Poultry building itself and the ventilation system have to provide an adequate physical environment for the animals. The physical environment inside the poultry buildings is determined by climatic variables, such as temperature, relative humidity, and air quality, with temperature being the most widely studied variable. Temperature is one of the many aspects of achieving environmental control in poultry buildings (ASAE, 2003). Other aspects include provision of adequate ventilation, illumination, photoperiod, humidity, noise levels and aerial pollutant levels. These variables are affected by the interaction between the outdoor weather conditions and the livestock, building and ventilation system. The most basic and common form of controlling the poultry housing environment is maintaining temperature inside the building within a desired range by adjusting ventilation and heating rates and cooling rate in hot climates. The control actions are based on feedback measurements of ambient temperature collected from one or more locations in the building (Schauberger et al., 2000; Hamrita and Mitchell, 1999).

Energetic analyses can give the ability for producers that compare all processing unit with modern production approach or even can alter the production lines (Jekayinfa, 2007). Insulation is one of the best ways for management of energy and reducing energy loses in the form of heat especially in cold areas with long winters. By this approach, the heat losses from heaters and broilers body are not lost and broilers can utilize feed energy for their growth. Managing equipment and consumption patterns in reducing utilize energy and therefore in reducing costs are effective. All of these ingredients and rapid increase in production cost of broilers have caused producers to have more attention to their energy consumption (Alam et al., 2005).

Mutai et al. (2011) developed a model to simulate the temperature changes at the closed house for broiler using an empirical mathematical model based on the law of thermal equilibrium. The temperature in a closed house is determined by ventilation and construction materials. The 
model produces accurate temperature tendency towards a certain time. That are average measured and predicted of temperatures of 24.43 and $24.40{ }^{\circ} \mathrm{C}$ and relative humidity ranged from 60 to $90 \%$ with a correlation coefficient $\left(\mathrm{R}^{2}\right) 0.978$.

Osorio et al. (2011) developed and validated a simplified steady state mathematical model to predict temperature distribution in a commercial poultry house equipped with a negative pressure ventilation system and internal misting. The model was validated with data obtained experimentally during the summer. For external temperature conditions of 26,27 and $29^{\circ} \mathrm{C}$, the best combinations of energy generated by misting, ventilation rate, global heat loss coefficient for the roof and global heat loss coefficient for the wall were encountered to maintain the majority of the installation with temperatures within the optimal thermal comfort range for the birds $\left(24\right.$ to $\left.29^{\circ} \mathrm{C}\right)$.

One of the main problems that hinder a chicken meat production is increased energy costs for heating and cooling, therefore, the main objective of this study is to develop a simulation model of energy balance to predict the energy gain or loss of poultry houses that made of different materials in order to save energy and reduce costs.

\section{MODEL DEVELOPMENT}

Energy balance was performed on the poultry house. The energy exchange due to both external and internal energy loads is shown in Figure (1). The external loads are transmission, fenestration, perimeter, ventilation and infiltration. The internal loads are occupants, lighting, and appliances. The internal and fenestration loads are always sources of heat gain. Ventilation, infiltration, perimeter, and heat transmission loads cause heat loss in winter months and heat gain in summer months.

The following assumptions for development of the present model are made:

- The model is based on steady-state conditions.

- The temperature of air is uniform across the whole building.

- The density and heat capacity of air are constant.

- The temperature gradients within the constructions are negligible.

- The building walls have negligible heat capacity. 
Equations (1) and (2) present the energy balance components of the poultry house:

$$
\begin{aligned}
& \mathrm{dQ} / \mathrm{dt}=\mathrm{Q}_{\mathrm{S}}+\mathrm{Q}_{\text {fens. }}+\mathrm{Q}_{\text {light }}+\mathrm{Q}_{\text {appliances }} \pm \mathrm{Q}_{\text {conv. }} \pm \mathrm{Q}_{\text {cond }} \pm \mathrm{Q}_{\mathrm{p}} \\
& \mathrm{Q}_{\text {solar }}=S H G C \times A_{w}\left(\mathrm{Q}_{\mathrm{D}}+\mathrm{Q}_{\mathrm{d}}+\mathrm{Q}_{\mathrm{r}}\right)
\end{aligned}
$$

Where:

Q is the total energy at any time in the poultry house, $\mathrm{J}$

$\mathrm{Q}_{\mathrm{s}}$ is the occupants (poultries) heat gains, $\mathrm{W}$

$\mathrm{Q}_{\text {fens. }}$ is the solar heat gains from windows, $\mathrm{W}$

SHGC is the solar heat gain coefficient, dimension less

$\mathrm{A}_{\mathrm{w}}$ is the window area, $\mathrm{m}^{2}$

$\mathrm{Q}_{\mathrm{D}}$ is the beam direct irradiance, $\mathrm{W}$

Qd is the sky diffuse irradiance, $\mathrm{W}$

Qr is the ground-reflected diffuse irradiance, W

$\mathrm{Q}_{\text {light }}$ is the heat gain by light, $\mathrm{W}$

Qappliances is the heat gain by appliances, W

$\mathrm{Q}_{\text {conv. }}$ is the heat exchange with the air by convection, W

$\mathrm{Q}_{\text {cond. }}$ is the heat exchange with the wall by conduction, $\mathrm{W}$

$\mathrm{Q}_{\mathrm{p}}$ is the heat exchange by perimeter of floor, $\mathrm{W}$

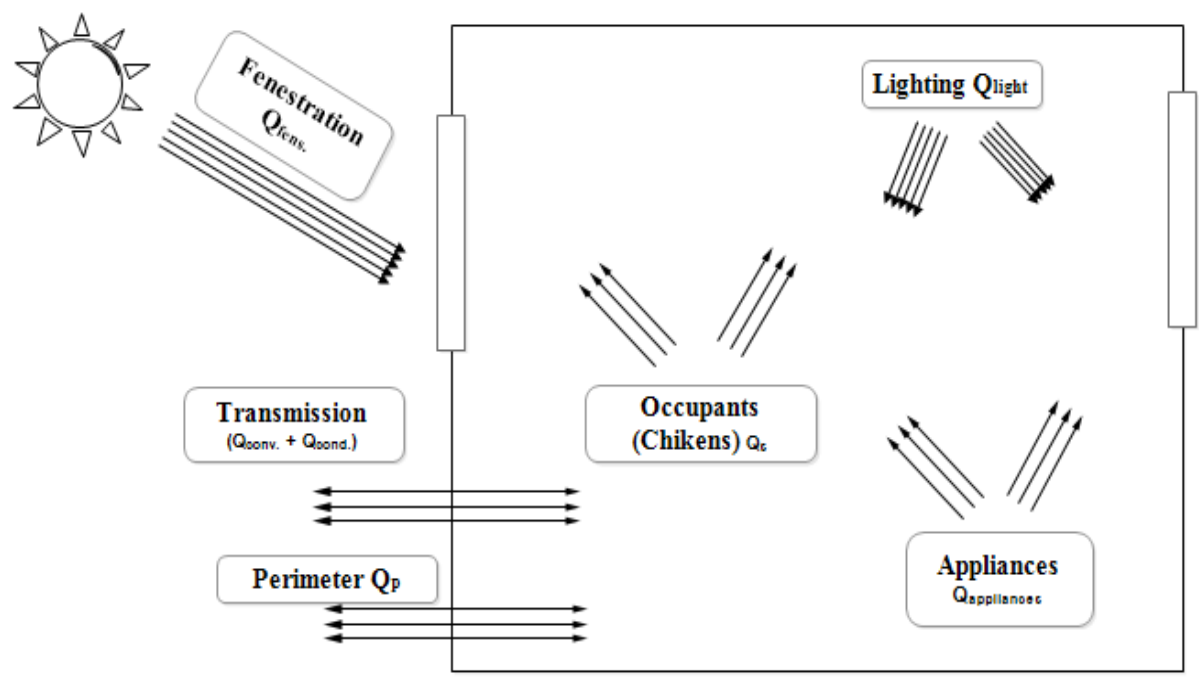

Figure (1): Energy balance of poultry house. 
Sensible heat generated by the occupants (poultries) can be described by the following equation (ASHRAE, 2013):

$\mathrm{Q}_{\mathrm{s}}=\mathrm{Q}_{\mathrm{s}, \text { perkg }} \times$ No. of broilers $\times$ avg. weight $\times\left(\frac{\text { Avg. weight }}{\text { total weight }}\right)^{0.734}$

Where:-

$\mathrm{Q}_{\text {s per kg }}$ is the sensible heat generated per $\mathrm{kg}, \mathrm{W} \mathrm{kg}^{-1}$

Radiation emitted by the sun travels through the vacuum of space unaltered. The percentage of energy associated with certain bandwidths of solar radiation emitted from a blackbody at 5800K (Holman, 1997). To determine the direct beam solar heat gain $\left(\mathrm{q}_{\mathrm{D}}\right)$ can be calculated according to the following equation (ASHRAE, 2003):

$$
\text { If } \cos (\theta) \succ 0 \stackrel{\text { then }}{\longrightarrow} \mathrm{Q}_{\mathrm{D}}=\mathrm{E}_{\mathrm{DN}} \cos (\theta), \stackrel{\text { otherwise }}{\longrightarrow} \mathrm{Q}_{\mathrm{D}}=0
$$

Where:

$\mathrm{E}_{\mathrm{DN}}$ is the surface direct irradiance, $\mathrm{W}$

$\theta$ is the solar incident angle, degrees

The surface direct irradiance is given by the following equation (ASHRAE, 2001):

$$
\text { If } \beta \succ 0 \stackrel{\text { then }}{\longrightarrow} \mathrm{E}_{\mathrm{DN}}=C_{n} A e^{-B / \sin \beta}, \stackrel{\text { otherwise }}{\longrightarrow} \mathrm{E}_{\mathrm{DN}}=0
$$

Where:

$\mathrm{C}_{\mathrm{n}}$ is the clearness number

$\beta$ is the solar altitude angle, degrees

$\mathrm{A}$ is the apparent solar radiation, $\mathrm{W} \mathrm{m}^{-2}$

$\mathrm{B}$ is the atmospheric extinction coefficient, dimensionless

The solar incident and altitude angles are given by the following equations (ASHRAE, 2009):

$$
\begin{gathered}
\cos \theta=\cos \beta \cos \gamma \cos \Sigma+\sin \beta \sin \Sigma \\
\sin \beta=\cos L \cos \delta \cos H+\sin L \sin \delta
\end{gathered}
$$




$$
\begin{gathered}
\delta=23.45 \sin \left[\frac{360}{365}(284+n)\right] \\
H=(A S T-12) \times 15^{\circ} \\
A S T=L S T+\frac{E T}{60}+\left(\frac{L O N-L S M}{15}\right) \\
E T=2.2918(0.0075+0.1868 \cos (T)-3.0277 \sin (T)-1.4615 \cos (2 T)-4.089 \sin (2 T)) \\
L S M=15 \mathrm{TZ} \\
T=360 \frac{n-1}{365}
\end{gathered}
$$

Where:

$\gamma$ is the solar azimuth angle, degrees

$\sum$ is the surface tilt angle from the horizontal plane, degrees

$\mathrm{L}$ is the local latitude angle (positive for North), degrees

$\delta$ is the solar declination angle (the angle formed by the line from the center of the Earth to the center of the Sun and the Earth's equator), degrees

$\mathrm{n}$ is the day of the year (on January $1 \mathrm{st}, \mathrm{n}=1$ )

$\mathrm{H}$ is the hour angle, degrees

AST is the apparent solar time, hour

LST is local standard time, hour

ET is the equation of time, minutes

LON is the longitude of the building, degrees

LSM is the longitude of local standard time meridian, degrees

$\mathrm{TZ}$ is the time zone, degrees

The solar azimuth $(\gamma)$ is the angle formed by the building and direct incident beam radiation and this angle varies with the time of day, the time of year and the geographical position of the house. The solar azimuth is given by the following equation (ASHRAE, 2009):

$$
\gamma=A \sin \left(\frac{\cos \delta \sin H}{\cos \beta}\right)
$$

Apparent solar radiation and atmospheric extinction coefficient are calculated by the following equations (ASHRAE, 2009):

$$
A=1147.5868+57.4985 \times \sin (0.0174 n+1.4782)
$$




$$
B=0.1639+0.0237 \times \sin (0.0202 n+4.013)
$$

The Diffuse component coming from the sky is calculated as follows (ASHRAE, 2001):

$$
Q_{d}=C Y E_{D N} \mathrm{~F}_{\mathrm{ss}}
$$

Where:

$\mathrm{C}$ is the coefficient of dispersion of solar radiation, dimensionless

$\mathrm{Y}$ is the ratio of the sky diffuse irradiation on vertical surfaces to the sky diffuse irradiation on horizontal surfaces

$F_{s s}$ is the angle factor between the surface and the sky

Coefficient of dispersion of solar radiation is given by the following equation (ASHRAE, 2009):

$$
C=0.120682346+0.017896423 \times \sin \left(\frac{0.020929536132 n}{3.97985854}\right)
$$

The ratio of the sky diffuse irradiation on vertical surfaces to the sky diffuse irradiation on horizontal surfaces is calculated by the following equation (ASHRAE, 2009):

If $\cos \theta \succ-0.2, \mathrm{Y}=0.55+0.437 \cos \theta+0.313 \cos ^{2} \theta$, otherwise $\mathrm{Y}=0.45$

The angle factor between the surface and the sky is given by the following equation (ASHRAE, 2003):

$$
F_{\text {ss }}=\frac{1+\cos \Sigma}{2}
$$

The reflectivity of solar radiation varies with the angle of incidence of the incoming radiation. The reflected shortwave radiation $\mathrm{Q}_{\mathrm{r}}$, is computed as (ASHRAE, 2009):

$$
Q_{\mathrm{r}}=E_{D N}(C+\sin \beta) \rho_{g}\left(\frac{1-\cos \Sigma}{2}\right)
$$

Where:

$\rho_{\mathrm{g}}$ is the ground reflectivity

The conduction of heat between the inner surface and the outer surface was calculated as: 


$$
Q_{\text {cond }}=k A\left(T_{i}-T_{o}\right) / z
$$

Where:-

$\mathrm{k}$ is thermal conductivity coefficient, $\mathrm{W} \mathrm{m}^{-1} \mathrm{~K}^{-1}$

A is the surface area, $\mathrm{m}^{2}$

$T_{i}$ is temperature of the inner wall surface, $K$

$T_{0}$ is temperature of the outer wall surface, $K$

$\mathrm{z}$ is thickness of wall surface, $\mathrm{m}$

Heat transferred through convection can be calculated using Newton's Law of cooling:

$$
q_{c o n v}=h A\left(T_{i}-T_{o}\right)
$$

Where

$\mathrm{h}$ is the heat transfer coefficient, $\mathrm{W} \mathrm{m} \mathrm{m}^{-2} \mathrm{~K}^{-1}$

Nusselt number $(\mathrm{Nu})$ correlations are traditionally used to predict a heat transfer coefficient as the following equation:

$$
h=N u \frac{k}{L c}
$$

Where

$\mathrm{L}_{\mathrm{c}}$ is the characteristic length of the surface, $\mathrm{m}$

$$
L_{c}=\frac{\text { Area }}{\text { Perimeter }}
$$

For the case of free convective surfaces, the Nusselt number is related to another dimensionless number, the Rayleigh number (Ra), through empirical correlations. The Rayleigh number is:

$$
R_{a}=\frac{g \beta\left(T_{i}-T_{o}\right) L_{c}^{3}}{v^{2}} \cdot \frac{\mathrm{C}_{\mathrm{p}} \mu}{k}
$$

Where

$\mathrm{g}$ is the gravitational acceleration, $9.81 \mathrm{~m} \mathrm{~s}^{-2}$

$\beta$ is the coefficient of thermal expansion, $\mathrm{K}^{-1}$

$\mathrm{v}$ is the kinematic viscosity of the fluid, $\mathrm{m}^{2} \mathrm{~s}^{-1}$

$\mu$ is the dynamitic viscosity of the air, $\mathrm{kg} \mathrm{m}^{-1} \mathrm{~s}^{-1}$

$\mathrm{C}_{\mathrm{p}}$ is the specific heat of air, $\mathrm{J} \mathrm{kg}^{-1} \cdot \mathrm{K}^{-1}$ 
Extinction coefficient is given by the following equation:

$$
\begin{array}{r}
\beta=\frac{1}{T_{f}} \\
T_{f}=\frac{T_{i}+T_{o}}{2}
\end{array}
$$

The Nusselt number and given for horizontal or vertical planes as follows (ASHRAE, 2001):

$$
\begin{gathered}
\mathrm{Nu}=0.56 \mathrm{Ra}^{0.25} \quad \text { if } \mathrm{Ra} \text { is between } 10^{4} \text { and } 10^{8} \\
\mathrm{Nu}=0.13 \mathrm{Ra}^{1 / 3} \quad \text { if } \mathrm{Ra} \text { is between } 10^{8} \text { and } 10^{12}
\end{gathered}
$$

For cases where wind is present (i.e. forced convection), different flat plate correlations could be used but run the risk of not being appropriate. The following Nusselt number correlation for mixed laminar and turbulent flow regions (for $5 \times 10^{5}<\operatorname{Re}<10^{8}$ ) can be used (Holman, 1997):

$$
N u=\left(0.037 \operatorname{Re}^{4 / 5}-871\right) \operatorname{Pr}^{1 / 3}
$$

Where

Re is the Reynold's number

Pr is the Prandtl number

The previous equation is valid for Prandtl numbers between 0.6 to 60 . The Reynold's number, Re, is a dimensionless number representing the ratio of inertial to viscous forces in the boundary layer of the fluid. It can be calculated as follows:

$$
\operatorname{Re}=\frac{V \cdot \operatorname{Lc}}{\mu}
$$

Where

$\mathrm{V}$ is the velocity of the air, $\mathrm{m} \mathrm{s}^{-1}$

The Prandtl number, $\mathrm{Pr}$, is a dimensionless number representing the ratio of the ability of a fluid to diffuse momentum to that of heat. It can be calculated as follows:

$$
\operatorname{Pr}=\frac{v}{\alpha}
$$


Where

$\alpha$ is the thermal diffusivity of the fluid, $\mathrm{m}^{2} \mathrm{~s}^{-1}$

Heat transfer according to perimeter can be estimated by the following equation for both unheated and heated slab floors (ASHRAE, 2001):

$Q_{p}=F P\left(T_{i}-T_{o}\right)$

Where:

$\mathrm{F}$ is the heat loss coefficient per foot of perimeter, $\mathrm{W} \mathrm{m} \mathrm{K}^{-1}$

$\mathrm{P}$ is the perimeter of floor, $\mathrm{m}$

The primary source of heat from lighting comes from light-emitting elements, or lamps, although significant additional heat may be generated from associated appurtenances in the light fixtures that house such lamps. Generally, the instantaneous rate of heat gain from electric lighting may be calculated from (ASHRAE, 2013):

$$
Q_{\text {light }}=W F_{u l} \mathrm{~F}_{\mathrm{sa}}
$$

Where:

$\mathrm{W}$ is the total light wattage, $\mathrm{W}$

$\mathrm{F}_{\mathrm{ul}}$ is the lighting use factor

$\mathrm{F}_{\mathrm{sa}}$ is the lighting special allowance factor

Heat gain by equipment is calculated from Arora (2006):

$$
Q_{\text {euip }}=(\text { input })-(1-\text { Motor Efficiency })
$$

All computational procedures of the model were carried out using Microsoft Visual Basic 2013. The program graphical user interface with the data input window below are in figure (2). The computer program was devoted to heat balance for predicting the temperature and energy gain or loss of poultry houses. Figure (3) show the flowchart of the model.

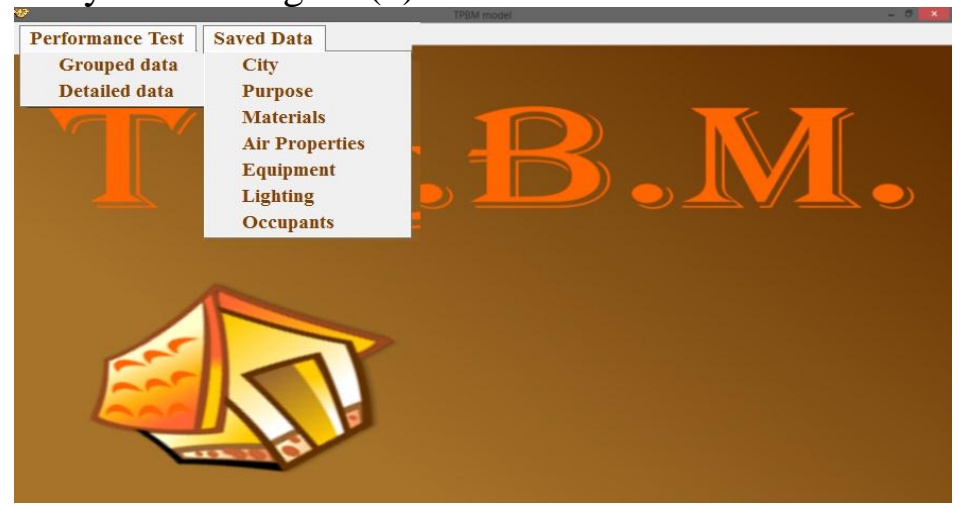

Figure (2): The program main working interface. 


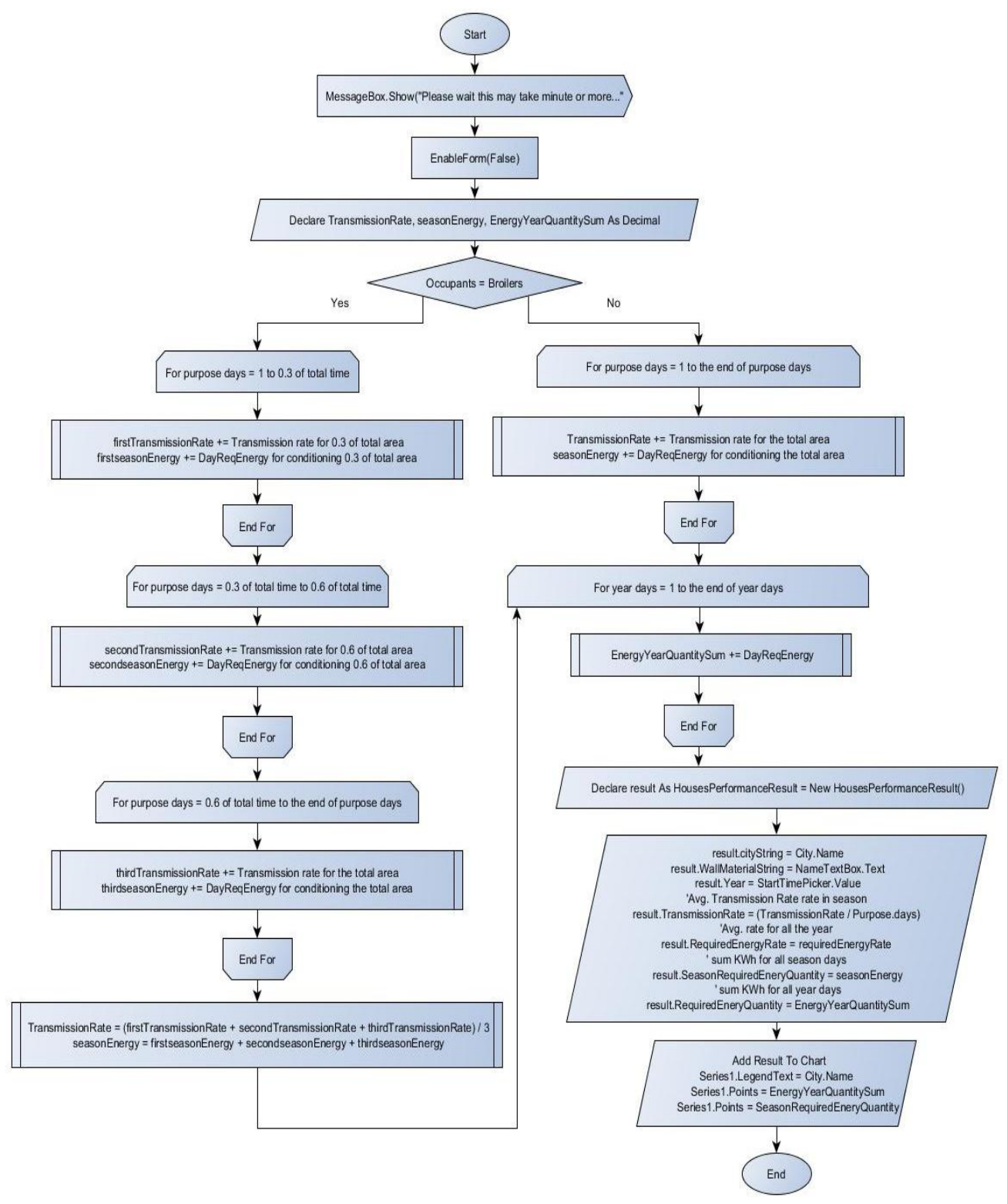

Figure (3): The flowchart of the model.

The poultry house consists of four houses, first house consists of walls made of bricks and roof concrete, second house consists of walls made of bricks and roof wood-boards, third house consists of walls made of bricks and straw bales and roof wood-boards and fourth house consists of walls made of straw bales and roof wood-boards. The parameters used in the model that were obtained from the literature are listed in table (1). 
Table (1): the parameters used in the energy balance.

\begin{tabular}{|l|l|c|l|}
\hline Parameter & Units & Value & Source \\
\hline $\mathrm{V}$ & $\mathrm{m} \mathrm{s}^{-1}$ & 0.5 & ASHRAE, 2001 \\
\hline $\mathrm{F}$ & $\mathrm{W} \mathrm{m}^{-1} \mathrm{~K}^{-1}$ & 1.2 & ASHRAE, 2001 \\
\hline LSM & Degree & 30 & \\
\hline Appliances power & $\mathrm{W}$ & 25 & \\
\hline Appliances efficiency & $\%$ & 75 & \\
\hline $\mathrm{F}_{\mathrm{ul}}$ & - & 1 & \\
\hline $\mathrm{F}_{\mathrm{sa}}$ & - & 1 & \\
\hline Hardwoods $(\mathrm{K})$ & $-\mathrm{W} \mathrm{m}^{-1} \mathrm{k}^{-1}$ & 0.166 & ASHRAE, 2009 \\
\hline Red brick (K) & $\mathrm{W} \mathrm{m}^{-1} \mathrm{k}^{-1}$ & 0.7 & ASHRAE, 2001 \\
\hline Straw $(\mathrm{K})$ & $\mathrm{W} \mathrm{m}^{-1} \mathrm{k}^{-1}$ & 0.042 & ASHRAE, 200 \\
\hline Concrete $(\mathrm{K})$ & $\mathrm{W} \mathrm{m}^{-1} \mathrm{k}^{-1}$ & 0.93 & ASHRAE, 2001 \\
\hline Glass $(\mathrm{K})$ & $\mathrm{W} \mathrm{m}^{-1} \mathrm{k}^{-1}$ & 1.2 & ASHRAE, 2001 \\
\hline SHGC & - & $0.25-0.6$ & \\
\hline $\mathrm{P}_{\mathrm{g}}$ & - & 0.2 & \\
\hline $\mathrm{C}_{\mathrm{n}}$ & - & 0.665 & Ibrahim, 2011 \\
\hline$\Sigma$ & Degree & 90 & \\
\hline
\end{tabular}

\section{EXPERIMENTAL PROCEDURES}

The experiment was carried out at some chicken meat production farms at El-Dakahia, El-Gharbia, El-Sharkia and El-Qalubia Governorates, Egypt. Table (2) shows the specifications of chicken meat buildings.

Table (2): The specifications of chicken meat buildings.

\begin{tabular}{|c|c|c|c|c|c|c|}
\hline \multirow{2}{*}{\multicolumn{2}{|c|}{ Specifications }} & \multicolumn{5}{|c|}{ Poultry house } \\
\hline & & 1 & 2 & 3 & 4 & 5 \\
\hline \multicolumn{2}{|c|}{ Location } & El-Dakahlia & El-Gharbia & El-Sharkia & El- Qalubia & El- Dakahlia \\
\hline \multirow{3}{*}{$\begin{array}{l}\text { Dimensions, } \\
\mathrm{m}\end{array}$} & Length & 64 & 93 & 70 & 40 & 100 \\
\hline & Width & 12 & 12 & 16 & 10 & 12 \\
\hline & Height & 3.5 & 3.5 & 3.5 & 3.5 & 3.5 \\
\hline \multirow{2}{*}{ Wall } & Materials & Bricks & Bricks & Bricks & Bricks & Bricks \\
\hline & Thickness, $\mathrm{m}$ & 0.2 & 0.2 & 0.2 & 0.2 & 0.2 \\
\hline \multirow[t]{2}{*}{ Roof } & Materials & $\begin{array}{c}\text { Asbestos } \\
\text { board }\end{array}$ & $\begin{array}{c}\text { Asbestos } \\
\text { board }\end{array}$ & $\begin{array}{c}\text { Asbestos } \\
\text { board }\end{array}$ & $\begin{array}{c}\text { Asbestos } \\
\text { board }\end{array}$ & $\begin{array}{c}\text { Asbestos } \\
\text { board }\end{array}$ \\
\hline & Thickness, $\mathrm{m}$ & 0.05 & 0.07 & 0.07 & 0.07 & 0.05 \\
\hline \multirow{2}{*}{ Ground } & Materials & Concrete & Concrete & Concrete & Concrete & Concrete \\
\hline & Thickness, $\mathrm{m}$ & 0.1 & 0.1 & 0.1 & 0.1 & 0.1 \\
\hline \multirow{2}{*}{ Windows } & Materials & Glass & Glass & Glass & Glass & Glass \\
\hline & Area, $\mathrm{m}^{2}$ & 152 & 225 & 220 & 80 & 235 \\
\hline \multirow{2}{*}{ Door } & Materials & Wood & Wood & Wood & Wood & Wood \\
\hline & Area, $\mathrm{m}^{2}$ & 4 & 4 & 4 & 4 & 4 \\
\hline \multirow{3}{*}{ Lighting } & Type & LED & LED & LED & LED & LED \\
\hline & Number & 48 & 60 & 58 & 34 & 52 \\
\hline & Power, W & 15 & 15 & 12 & 12 & 12 \\
\hline \multicolumn{2}{|c|}{ No. of chickens } & 7500 & 1500 & 12000 & 4500 & 13000 \\
\hline \multicolumn{2}{|c|}{ Final weight, kg } & 1.5 & 0.4 & 1.25 & 1.5 & 0.45 \\
\hline
\end{tabular}


Gas consumption of heating poultry houses was recorded daily to calculated energy requirement for heating chicken meat houses. The energy consumption recorded was used to validate the predicted energy from the energy balance model. The specific heat of gas consumption for heating poultry house is $6600 \mathrm{Kwhh}$ per $\mathrm{m}^{3}$ (12.9 Kwhh per $\left.\mathrm{kg}\right)$.

\section{RESULTS AND DISCUSSION}

\subsection{Model Experimentation:}

Figure (4) shows the energy requirement for heating poultry houses for different poultry houses: First house consists of walls made of bricks and roof concrete, second house consists of walls made of bricks and roof wood-boards, third house consists of walls made of bricks and straw bales and roof wood-boards and fourth house consists of walls made of straw bales and roof wood-boards in Faiyum, Damietta, Benha and Loxur cities during winter season (January and February). The results indicate that the energy requirement for heating chicken house decreases with increasing chicken age (40 days). It could be seen that the energy requirement for heating was decreased from 3716.75 to $247.65,2731.31$ to $10.79,2417.98$ to 66.14 and 2418.06 to $66.18 \mathrm{Kwhh}$ for first, second, third and fourth houses, respectively, when the chicken age increased from 1 to 40 days in Faiyum city.

The energy requirement for heating was decreased from 5381.37 to $1048.13,4052.34$ to $633.16,3631.94$ to 499.39 and 3632.05 to 499.41 Kwhh in Damietta city, while it was deceased from 6602.23 to 701.29 , 5030.31 to $364.65,4534.72$ to 255.98 and 4534.86 to $255.99 \mathrm{Kwhh}$ in Benha city and it was decreased from 5800.86 to $1478.65,4387.63$ to 978.17, 3941.12 to 818.06 and 3941.25 to $818.10 \mathrm{Kwhh}$ in Luxor city for first, second, third and fourth chicken houses, respectively, when the chicken age increased from 1 to 40 days. Decreasing energy requirement with increasing the chicken age due to the optimum temperature for chicken during the first stage of age ranged from 33 to $35^{\circ} \mathrm{C}$, then the optimum temperature for chicken decreased with increasing the chicken age (the optimum temperature about $18^{\circ} \mathrm{C}$ at the end of production period). These results agreed with those obtained by Eekeren $\boldsymbol{e t} \boldsymbol{a l}$. (2006). 


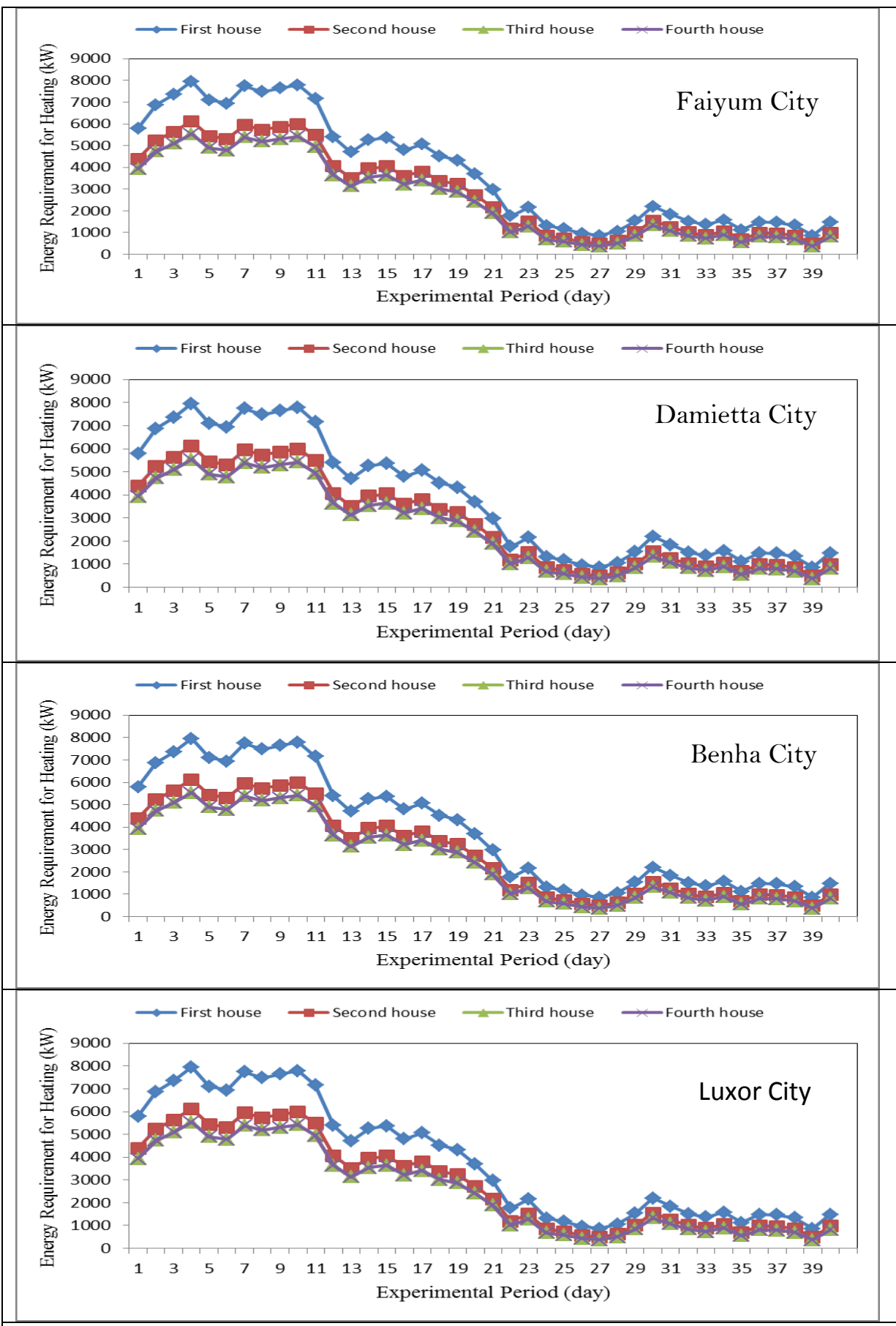

Figure (4): The energy requirement for heating poultry houses in Faiyom, Damietta, Benha and Loxur cities during winter season. 
Figure (5) shows the energy requirement for ventilation poultry houses for different poultry houses: First house consists of walls made of bricks and roof concrete, second house consists of walls made of bricks and roof wood-boards, third house consists of walls made of bricks and straw bales and roof wood-boards and fourth house consists of walls made of straw bales and roof wood-boards in Faiyum, Damietta, Benha and Loxur cities during summer season (July and August). The results indicate that the energy requirement for ventilation chicken house increases with increasing chicken age (40 days). It could be seen that the energy requirement for ventilation was increased from 1517.24 to 4083.08, 1325.53 to $3326.87,1262.20$ to 3084.95 and 1262.21 to $3085.00 \mathrm{Kwhh}$ for first, second, third and fourth houses, respectively, when the chicken age increased from 1 to 40 days in Faiyum city.

The energy requirement for ventilation was increased from 2817.64 to $3750.08,2336.24$ to $3072.11,2180.88$ to 2855.29 and 2180.91 to 2855.34 Kwhh in Damietta city, while it was increased from 2373.09 to 6793.56, 1991.44 to $5477.08,1867.80$ to 5060.30 and 1867.81 to $5060.41 \mathrm{Kwhh}$ in Benha city and it was increased from 2467.29 to $7569.91,2064.67$ to 6096.04, 1934.51 to 5630.40 and 1934.53 to $5630.53 \mathrm{Kwhh}$ in Luxor city for first, second, third and fourth chicken houses, respectively, when the chicken age increased from 1 to 40 days. Increasing energy requirement for ventilation with increasing the chicken age due to the optimum temperature for chicken during the first stage of age ranged from 33 to 35 ${ }^{\circ} \mathrm{C}$, then the optimum temperature for chicken decreased with increasing the chicken age (the optimum temperature about $18^{\circ} \mathrm{C}$ at the end of production period). These results agreed with those obtained by Eekeren et al. (2006).

\subsection{Model validation:}

Figure (6) shows the predicted and the measured energy requirement for heating five poultry houses at El-Dakahia, El-Gharbia, El-Sharkia and ElQalubia Governorates during winter season (January and February). It could be seen that, the predicted energy requirements were in a reasonable agreement with those measured, where, They were 35088.14, 34470.12, 43.111.39, 19217.72 and 29188.30 Kwhh for first, second, third, fourth and fifth poultry houses, respectively, theoretically while they were 4529.06, 31058.78, 40.764.65, 24264.67 and 31058.78 Kwhh experimentally. 


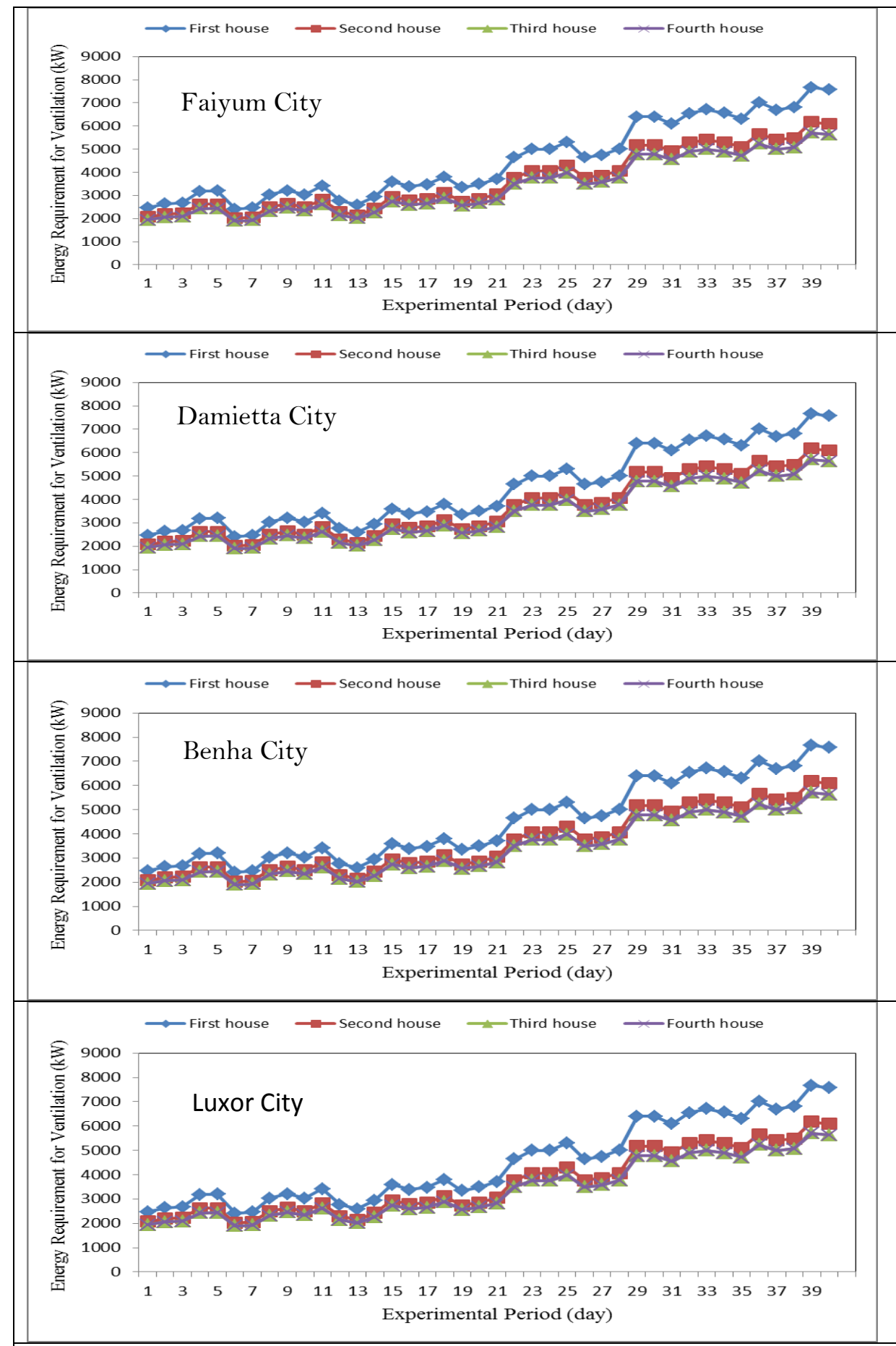

Figure (5): The energy requirement for ventilation chicken houses in Faiyom, Damietta, Benha and Loxur cities during winter season. 


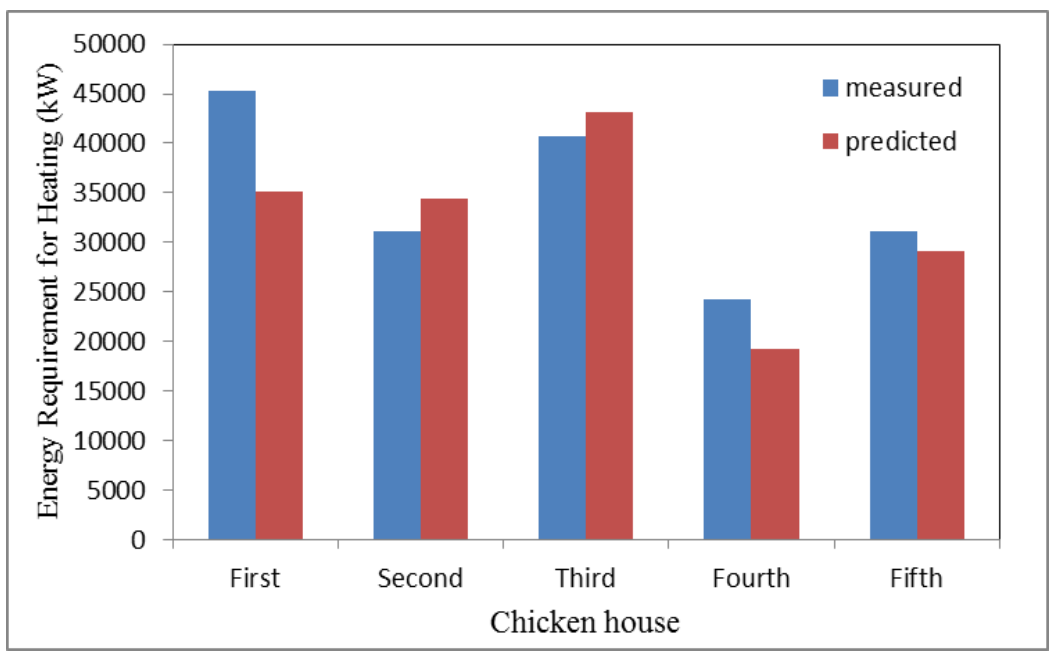

Figure (6): The predicted and the measured energy requirement for heating different poultry houses.

\section{CONCLUSIONS}

A simulation model for the poultry house was developed successively according to energy balance to optimize the main factors affecting the performance of poultry house through studying of energy requirement for different poultry house. Also, carrying out an experiment to validate the model results through measuring energy requirement for heating poultry house. The most important results obtained can be summarized as follows:

- The energy requirement for heating was decreased from 3716.75 to $247.65,2731.31$ to $10.79,2417.98$ to 66.14 and 2418.06 to 66.18 Kwhh for first, second, third and fourth houses, respectively, when the chicken age increased from 1 to 40 days in Faiyum city.

- The energy requirement for heating was deceased from 6602.23 to $701.29,5030.31$ to $364.65,4534.72$ to 255.98 and 4534.86 to 255.99 Kwh in Benha city, when the chicken age increased from 1 to 40 days.

- The energy requirement for ventilation was increased from 1517.24 to $4083.08,1325.53$ to $3326.87,1262.20$ to 3084.95 and 1262.21 to $3085.00 \mathrm{Kwh}$ for first, second, third and fourth houses, respectively, when the chicken age increased from 1 to 40 days in Faiyum city.

- The energy requirement for ventilation was increased from 2373.09 to $6793.56,1991.44$ to $5477.08,1867.80$ to 5060.30 and 1867.81 to 
$5060.41 \mathrm{Kwh}$ in Benha city, when the chicken age increased from 1 to 40 days.

- The energies requirement were $35088.14,34470.12,43.111 .39$, 19217.72 and 29188.30 Kwh for first, second, third, fourth and fifth chicken houses, respectively, theoretically while they were 4529.06, $31058.78,40.764 .65,24264.67$ and $31058.78 \mathrm{Kwh}$ experimentally.

\section{REFERENCES}

Alam, M. S., M. R. Alam and K. K. Islam (2005). Energy flow in agriculture: Bangladesh. Am. J. Environ. Sci., 3: 213 - 220.

Arora, C. P. (2006). Refrigeration and air conditioning. Second edition. McGraw-Hill. New Delhi.

ASAE (2003). Design of ventilation systems for Poultry and Livestock Shelters. ASAE, St Joseph, Michigan, pp: 634 - 652. Retrieved from: http://edis.ifas.ufl.edu.

ASHRAE (2001). Handbook heating, ventilating, and air-conditioning application Atlanta, GA: American Society of Heating, Refrigerating and Air-conditioning Engineers, Inc: 90.1.

ASHRAE (2003). Handbook Heating, Ventilating, and Air-Conditioning system and equipement. Atlanta, GA: The American Society of Heating, Refrigerating and Air Conditioning Engineers, Inc: 12.14.

ASHRAE (2009). Handbook heating, ventilating, and air-conditioning application Atlanta, GA: American Society of Heating, Refrigerating and Air-conditioning Engineers, Inc: 4.2.

ASHRAE (2013). Handbook heating, ventilating, and air-conditioning application Atlanta, GA: American Society of Heating, Refrigerating and Air-conditioning Engineers, Inc: 34.15.

Eekeren, N. V., A. Maas, H. W. Saatkamp, and M.Verschuur, (2006). Small-scale chicken production. Fourth edition, Agromisa Foundation and CTA, Wageningen.

Hamrita, T.K. and B. Mitchell (1999). Poultry environment and production control and optimization. A summary of where we are and where we want to go. Trans. ASAE, 42: 479 - 483.

Holman, J. P. (1997). Heat Transfer, 8th edition. McGraw-Hill. 696 pp. 
Ibrahim, A., A. A. El-Sebaii, M. R. Ramadan and S. M. El-Broullesy (2011). Estimation of Solar Irradiance on Inclined Surfaces Facing South in Tanta, Egypt. IJRER, 18-25

Jekayinfa, S. O. (2007). Energetic Analysis of Poultry Processing Operations. Leonardo Journal of Sciences, 10: 77 - 92.

Mutai, E. B. K., P. O. Otieno, A. N. Gitau, D. O. Mbuge and D. A. Mutuli (2011). Simulation of the Microclimate in Poultry Structures in Kenya. Journal of Applied Sciences Research, Engineering and Technology, 3 (7): 579 - 588.

Osorio, J. A. O., I. D. F. Tinôco, K. S. O. Rocha, M. A. Martins and M. O. De Paula (2011). Modeling and experimental validation to estimate the energy balance for a poultry house with misting cooling. Dyna., 78(170): 167-174.

Schauberger, G., M. Piringer and E. Petz (2000). Steady state balance model to calculate the indoor climate of livestock buildings demonstrated for finishing pigs. Int. J. Biometeorol., 43(17): 154162.

\section{الملخص العربيى \\ نموذج محاكاه لاتزان الطاقة لمساكن الدواجن المرين}

منار أحمد سعد*، السيد جمعه خاطر***، سمير احمد على** طه حسن عاشور**

تهدف هذا الدراسة إلى تطوير نموذج محاكاه لاتزان الطاقة فى مساكن الدواجن للتنبؤ بالطاقة

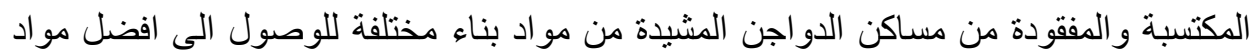

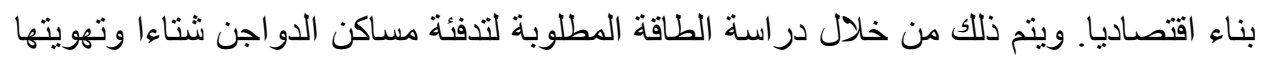

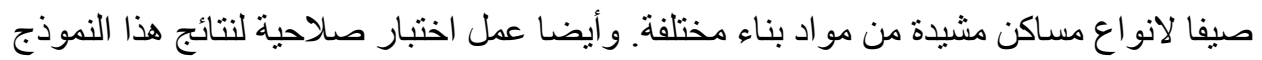

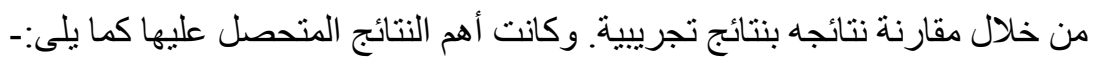

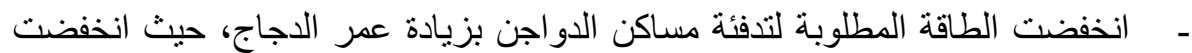

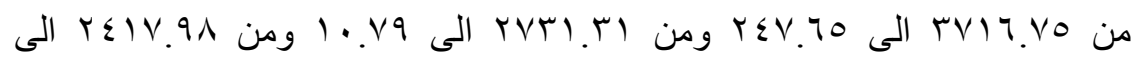

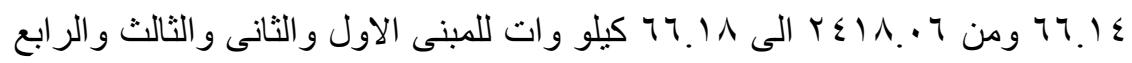

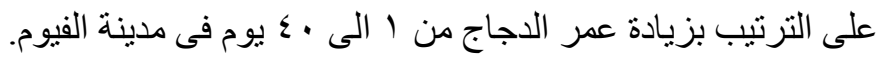

* طالبة دراسات عليا ـ كلية الزراعة بمشتهر - جامعة بنها

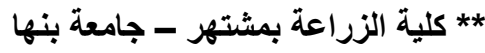


- انخفضت الطاقة المطلوبة لتدفئة مساكن الدواجن بزيادة عمر الدجاج، حيث انخفضت

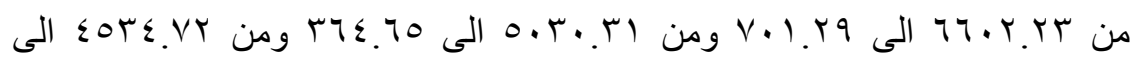

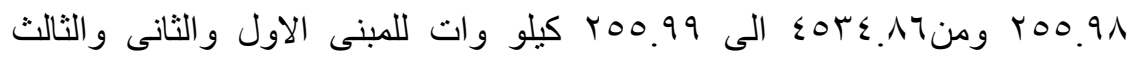
و الرابع على الترتيب بزيادة عمر الدجاج من ا الى . • يوم فى مدينة بنها.

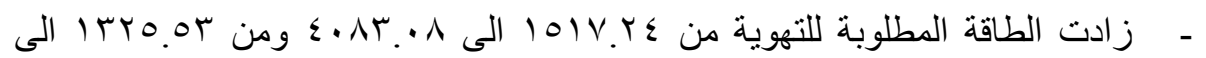

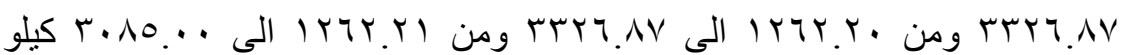

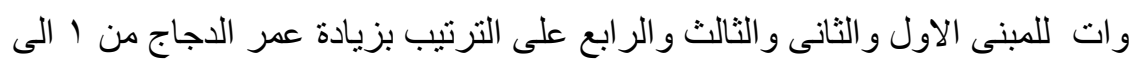
• ع بوم فى مدينة الفيوم.

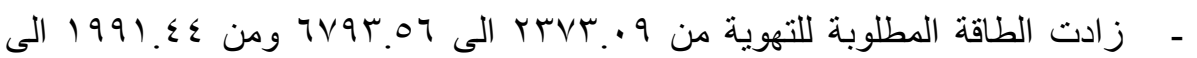

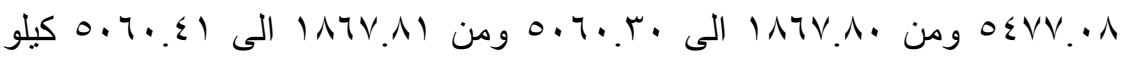

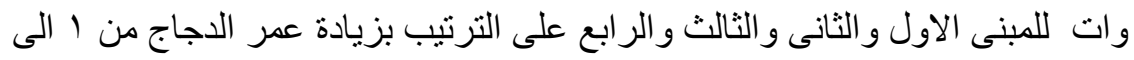
• ع بوم فى مدينة بنها. - وكانت نتائج النموذج الرياضى متفقة مع النتائج التجريبية. 